\title{
Coal Tailings as a Pozzolanic Material in Cements: A Preliminary Study for Their Use in Sleepers and Slab Track Railway System. Part I. Materials Selection
}

\author{
Santiago Yagüe ${ }^{1}$, Isabel Sánchez ${ }^{2}$, Raquel Vigil de la Villa ${ }^{3}$, Rosario García-Giménez ${ }^{*}$, Antonio Zapardiel ${ }^{4}$, \\ Moisés Frías ${ }^{5}$ \\ ${ }^{1}$ ETS. Ingenieros industriales, Universidad Nacional de Educación a Distancia (UNED). 28040, Madrid, \\ Spain; santiagooyg@hotmail.com \\ ${ }^{2}$ Facultad de Ciencias, Universidad Nacional de Educación a Distancia (UNED). 28040 Madrid, Spain; \\ isa.svigil@gmail.com \\ ${ }^{3}$ Dpto de Geología y Geoquímica, Unidad Asociada CSIC-UAM, Universidad Autónoma de Madrid (UAM), \\ 28049 Madrid, Spain; raquel.vigil@uam.es; rosario.garcia@uam.es \\ ${ }^{4}$ Facultad de Ciencias, Universidad Nacional de Educación a Distancia (UNED). 28040 Madrid, Spain; \\ azapardiel@ccia.uned.es \\ 5 Eduardo Torroja Institute (CSIC), Spanish National Research Council, 28033 Madrid, Spain; \\ mfrias@ietcc.csic.es
}

\begin{abstract}
:
One source of kaolinite-rich wastes is from mine tailings and the generation of enormous volumes of mine tailings waste is standard practice in this industry. These volumes of waste are, at present, dumped, provoking significant environmental impact and transforming the environment. The impact of storing coal waste requires the study of eco-innovative solutions for the assessment of waste types. The present investigation has the objective of expanding the knowledge on the behavior of new siliceous-aluminum minerals with pozzolanic activity, of added value in the manufacture of similar cements. Four samples were characterized to determine their chemical, morphological and mineralogical composition. The samples were subjected to different thermal activation conditions for the transformation of an inert waste into a material with cementitious properties. XRD analysis have confirmed the total transformation of kaolinite into metakaolinite. The results have shown that after the activation process, the coal refuse presented good pozzolanic activity, meaning that it may be used as a pozzolanic addition in industrial cements, thereby removing high levels of contaminated waste from the environment. In subsequent investigations, research work will continue with the replication of cements with this pozzolanic addition for use in the manufacture of sleepers and slab track railway system.
\end{abstract}

Keywords: coal tailing; cement; pozzolan; sleepers; slab track; railway

\section{Introduction}

Material and energetic recycling of raw materials found in waste that are produced in different productive sectors is a priority line of action. Therefore, the search for strategies that could promote the rotation of large volumes of industrial waste and associated by-products in the productive cycles is one of the main sources of economic opportunity. The examination of these strategies demands an exhaustive technical-scientific knowledge of the current research projects, with the purpose of giving these waste products an appreciable value in potential applications.

There is a prolific history of investigation behind the use of industrial wastes and by-products in cement and construction manufacturing processes, scientific-technical contributions, and competitive designs transferred to industry are still a mainstream research topic. Hence, a need is identified to diversify the sources and the supply of pozzolan mineral additives for use in the manufacture of cements and related materials. Therefore, the investigation in this area is oriented towards new pozzolanic fractions through the evaluation of industrial wastes and by-products that are specified in a range of cement standards [1-5]. One of these lines of 
investigation is closely related with the activation of materials that contain notable quantities of clay, principally kaolinite. The properties of Metakaolin (MK) generated by the controlled activation of natural kaolinite form a central research topic, core to numerous investigations [6-12].

The environmental impacts and human health problems caused in a coal-mining environment have also been investigated for a substantial time [13-17]. The environmental risks associated with coal mining may include changes to the landscape and land use, soil erosion, increased noise pollution, production of solid wastes, air pollution, surface and groundwater pollution, contamination of soils and sediments, land instability, subsidence, slag tip fires, and several impacts on local biodiversity [18-20]. The generation and disposal of solid wastes, dumping voluminous amounts of discarded mine tailings that provoke various environmental problems in addition to the above-mentioned. The disposal of coal-mine tailings may lead to: atmospheric dispersion of particles; spontaneous combustion of waste piles; landslides and mass movements in the waste piles; and mobilization of materials, leaching of elements and formation of acid drainage caused by weathering and/or oxidation processes.

One source of kaolinite-rich wastes is from mine tailings and the generation of enormous volumes of mine tailings waste is standard practice in the mining industry. These volumes of waste are, at present, dumped, provoking significant environmental impact and transforming the environment. According to the Spanish legislation on environmental matters and the laws on the Evaluation of Environmental Impact, all mining exploitations when at the end of their productive life, are obliged to submit a Plan for the Abandonment and Closure of the mine and put it into action along with by-product recycling.

The impact of storing coal waste requires the study of eco-innovative solutions for the assessment of waste types [21], with a view to the systematic recovery of mineral and energetic resources integrated at the lowest possible environmental costs. If metallic minerals are found alongside a series of impurities or mine-tailings, associated with coal mining, incombustible inorganic impurities will also reduce if not completely degrade coal quality.

In accordance with the specifications sheet prepared by CEDEX [22], mine-tailings refer to the excess waste after having extracted the coal, sourced from the exploitation of open-cast and underground mines (10\% of the total), as well as from the coal washing processes (90\%).

Thus, the present investigation has the objective of expanding our knowledge on the behavior of new siliceous-aluminum minerals with pozzolanic activity, of added value in the manufacture of similar cements and materials, obtained from the controlled thermal activation of coal waste.

The coal tailings extracted from the mines are stored for lengthy periods in the open air, undergoing natural weathering, and the accumulation of materials that provoke significant environmental contamination [23]. It is for this reason that an alternative use for the high volume of tailings, rich in clayey minerals forms the central topic of this preliminary study.

Weathering processes such as washing in water, and self-heating in coal waste dumps can create significant environmental problems. Mineral composition (especially pyrite), volatile matter, types of organic-matter, direct contact with water (wetting), and storage times are also important factors [24-28]. Poor compaction facilitates the penetration of both air and water, increasing the self-heating process.

\section{Materials and methods \\ 2.1. Materials}

The study area, located in El Bierzo County (Figure 1), in the province of Leon (Spain), is a coalfield of 310 $\mathrm{km}^{2}$, in an area that has been exploited since the mid-19 ${ }^{\text {th }}$ century [23]. Four types of samples were selected from the mines of the Sociedad Anónima Huellera Vasco - Leonesa, Santa Lucía, León, Spain (Figure 2 a). The first sample was mining (coal) refuse (overburden and waste rock), extracted at low levels, comprising top soil and overburden, waste-rock, and low-grade minerals. High volumes of these inert materials are found piled in slag tips in the area around the coalfield (Figure 2 b). The other three samples ("tailings") consisted of coal refuse from coal-flotation treatments that extract the coal from the crushed fines. The three samples were graded by particle size: coarse grade $(12.00$ to $0.50 \mathrm{~mm})$, fine grade $(0.50$ to $0.05 \mathrm{~mm})$, and very fine-grade samples $(<0.05 \mathrm{~mm})$ of coal waste. 


\subsection{Methods}

The four samples were characterized to determine their chemical composition (most abundant elements, traces, total organic coal content, sulfurs and loss on ignition), morphological and mineralogical (total and clayey minerals). The aforementioned samples were subjected to different thermal activation conditions (heating from 500 to $900^{\circ} \mathrm{C}$ over 2 hours in an electric furnace) for the transformation of an inert waste into a material with cementitious properties.

Different techniques were used:

1) The chemical characterization was performed with Inductively Coupled Plasma Mass Spectrometry (ICP/MS), prior to having immersed the sample in an acidic solution (ICP-MS Elan 6000 Perkin Elmer Sciex with an AS91 autosampler). The content of organic coal in the solid samples was determined by the difference between the total content of coal and inorganic coal, using a total organic carbon analyzer, the Shimadzu (Total Organic Carbon Analyzer) TOC-5000 A, with a module for solid samples (Solid Sample Module) SSM-5000 A.

2) The mineralogical composition was determined by X-ray diffraction (DRX) with the powder method and the $<2 \mu \mathrm{m}$ fraction with the oriented aggregate method; in both cases completing the diffractograms in a Siemens diffractometer D-5000 fitted with a $\mathrm{Cu}$ anode [29]. The characterization of the bulk samples was performed with the Rielveld method.

The SEM morphological observations and the EDX microanalysis were performed with an FEI electronic microscope equipped with an energy dispersive X-ray spectrometer (source of W, DX4i analyzer and Si / Li detector).

3) The determination of pozzolanic activity sheds light on the pozzolanic activity of pozzolan/hydroxide calcium (lime) systems using the solid waste after having applied an accelerated chemical method [2]. After 1,7 , and 28 days of reaction, the waste product was washed with acetone and dried in an electric furnace at $60^{\circ} \mathrm{C}$ over 24 hours, ending the pozzolanic reaction. The content of fixed lime was measured as the difference between the concentration of $\mathrm{CaO}(\mathrm{mmol} / \mathrm{L})$ in the initial saturated-lime solution $(17.68 \mathrm{mmol} / \mathrm{L})$ and the content of the same compound in the solution at set times.

\section{Results and discussion}

The mineralogical characterization of samples by XRD (Figure 3) identified a major presence of phyllosilicates (mica and kaolinite), accompanied by quartz, calcite, dolomite and feldspars. Given that the phyllosilicates are responsible for the pozzolanic activity, a decisive property in the use of pozzolan materials is found in the very fine-grade samples with the highest content of micas and kaolinite (48\%), as opposed to the coarse mining refuse with a lower content of those minerals (24\%). The other two tailing samples had intermediate values in relation to the rest of the mineral components, in all of which feldspar trace concentrations were found with variable quantities of calcite, dolomite and quartz, depending on each sample (Table 1). Silicate and aluminum-silicate minerals were dominant elements in all the samples.

SEM/EDX analysis of the very fine-grade coal sample indicated the presence of variable sizes of aggregates (Figure 4A). The aggregate surfaces were irregular (Figure 4B) filled with pores and cracks that assist their disaggregation. Idiomorphic crystal of pyrite was identified in the gaps of the layers of phyllosilicate, in dispersed and concentrated forms forming clusters (Figure 4C). The aggregates consisted of calcite, quartz and phyllosilicates (Figure 4D and Table 2). The grain sizes of the fine tailings were of greater uniformity (Figure 4E) and of larger size than those of the very fine grade coal sample, with phyllosilicate and quartz aggregates and pyrite crystals in the gaps between the layers of phyllosilicate (Figure 4F). The aggregates were, in general, of a compact appearance.

In turn, the presence of very compact aggregates in the coal field samples were generally formed of phyllosilicates, calcite, and quartz (Figure 5A). Phosphates, iron, calcium and magnesium accumulated in disordered and random concentrations mainly in the clayey aggregates (Figure 5B and Table 3). These varied concentrations occur due to the undulatory surface forms of the phyllosilicates (Figure 5C) with fractures and voids that facilitate deposits of the aforementioned elements (Figure 5D). The empty spaces of the aggregates were full of organic matter compacting them with disorderly deposits of pyrite crystals on their surface.

The chemical composition of the four samples (Table 4), indicated that they were all of a silico-aluminous nature with percentages $\left(\mathrm{SiO}_{2}+\mathrm{Al}_{2} \mathrm{O}_{3}\right)$ between $50 \%$ and $70 \%$ of the total weight, with a practically constant presence of iron oxide in all of them, with a very variable quantity of $\mathrm{CaO}$ (the fine-grade tailings with the highest percentage, $16.20 \%$, and the mining refuse with the lowest, $3.84 \%$ ), and likewise loss on ignition (very fine-grade samples with the highest weight loss, $26.47 \%$, and the mining refuse with the lowest, 
15.18\%). MnO was practically constant in all the samples, fluctuating between $0.87 \%$ and $0.59 \%$. The alkaline oxides $\left(\mathrm{Na}_{2} \mathrm{O}+\mathrm{K}_{2} \mathrm{O}\right)$ were approximately $2.46 \%$ in the very fine-grade samples and $2.87 \%$ in the mining refuse. Higher concentrations of $\mathrm{SO}_{3}$ were found in the fine-grade tailings $(0.92 \%)$ and the lowest concentrations were once again found in the mining refuse $(0.27 \%)$. Finally, concentrations of $\mathrm{P}_{2} \mathrm{O}_{5}$ were at their highest in the very fine-grade samples $(0.26 \%)$ and lowest in the mining refuse $(0.13 \%)$. The very fine tailings had the highest content of organic carbon $(24.27 \%)$, while the lowest content was found in the mining refuse $(16.04 \%)$.

Trace elements of $\mathrm{Ni}, \mathrm{Cr}, \mathrm{V}, \mathrm{Zn}, \mathrm{Pb}, \mathrm{As}$, Co and Mo were found in concentrations lower than 200 ppm (Table 5 ) that reportedly [30] had a direct influence on the rheological properties of the pozzolanic cements.

The chemical analyses indicated that the most appropriate sample for use as a coal-mining pozzolan waste would be the very fine-grade samples, with a granulometry $\leq 0.05 \mathrm{~mm}$, following flotation treatment of the tailings. Nevertheless, this product requires pre-flotation treatment after extraction, as previously mentioned, and low volumes are generated following the treatment, as against the quantity found in the mine refuse. In view of these comments, the mining refuse was selected for use as a pozzolanic addition.

Nevertheless, the selected sample (mining refuse) was calcinated within a thermal range of $600^{\circ} \mathrm{C}$ to $900^{\circ} \mathrm{C}$ after two hours in an electric furnace, which transforms the kaolinite into metakaolinite and simultaneously dehydroxylates the micas. The intention was to confirm this hypothesis, given that the most reactive state of the phyllosilicates occurs when the material is found in a dehydroxylated form, due to loss of the hydroxyl groups by calcination. The mineralogical composition by XRD of the calcinated samples at the various temperatures are presented in Table 6. The disappearance of both the kaolinite at $600^{\circ} \mathrm{C}$ (transformed into metakaolinite, unidentifiable by XRD due to its amorphousness) and the dolomite was noted; and that of the calcite at $800^{\circ} \mathrm{C}$. In addition, new phases of the hematites appeared at around $600^{\circ} \mathrm{C}$, due to water loss from both the oxyhydroxides and the iron oxides as well as the spinel, as a consequence of the thermal treatment of the aluminous minerals of the clay $[12,31]$.

A temperature of $600^{\circ} \mathrm{C}$ applied over 2 hours was selected as the ideal conditions for thermal activation of the coal waste, thereby economizing on energy, SEM/EDX observation shows the disaggregation of the aggregates, due to the destruction of the organic matter. The appearance of metakaolinite laminar aggregates with surface deposits of sulfur, potassium and calcium, as well as the appearance of aggregates with frayed laminates from the partial dehydroxylation of the remaining phyllosilicates (Figure $5 \mathrm{E}$ and Table 7).

The fundamental property for an industrial by-product to be used as an active cement additive is its pozzolanic properties. Figure 6 shows the graph of coal refuse (overburden, waste rock, and occasional lowgrade mineral waste) pozzolanic activity, activated at $600^{\circ} \mathrm{C} / 2 \mathrm{~h}$, over 90 days of reaction time. The analytic results, expressed as percentages of fixed lime indicate the high pozzolanic activity of the coal refuse activated at $600^{\circ} \mathrm{C}$, with very much higher values than those obtained with a commercial metakaolin (MK) at all ages (except at 28 days).

\section{Conclusions}

Four coal-mining wastes have been studied from the coalmines that have now closed, in Santa Lucía, León, Spain. From among them all, one was selected due to the presence of high volumes of waste and the facility of its use as an additional pozzolanic cement additive.

The coal refuse was thermally activated to improve the pozzolanic properties, selecting a temperature of $600^{\circ} \mathrm{C}$ over two hours in an electric furnace, which has advantages from both an economic and an energetic point of view.

The results of XRD analysis have confirmed the total transformation of the kaolinite into metakaolinite (a pozzolan specified in commercial cement manufacturing standards) that takes place at that temperature over the heating time $\left(600^{\circ} \mathrm{C} / 2 \mathrm{hours}\right)$.

The results have shown that after the activation process, the coal refuse presented good pozzolanic activity, meaning that it may be used as a pozzolanic addition in industrial cements, thereby removing high levels of contaminated waste from the environment. 
In subsequent works, research work will continue with the replication of cements with this type of pozzolanic additions for use in the manufacture of sleepers and slab track railway system.

Acknowledgments: This research has been supported by the Spanish Ministry of Economy and Competitiveness (Project Ref BIA2015-65558-C3-1-2-3R (MINECO/FEDER)). The authors are also grateful to the Sociedad Anónima Hullera Vasco-Leonesa and to the Spanish Cement Institute (IECA) for their assistance with this research.

Author Contributions: Moisés Frías and Raquel Vigil de la Villa Mencía conceived and designed the experiments; Santiago Yagüe contributed materials and performed the experiments; Isabel Sánchez and Antonio Zapardiel analyzed the data; Rosario García-Giménez wrote the paper.

Conflicts of Interest: The authors declare no conflict of interest.

\section{References}

1. Frías, M.; Sánchez de Rojas, M.I.; Santamaría, J.; Rodríguez, C. Reclycling of silicomanganese slag as a pozzolanic material in Portland cements: Basic and engineering properties. Cem. Concr. Res. 2006, 36 (3), 487 - 491.

2.Frías, M.; Villar-Cociña, E.; Savastano, H. (2011). Brazilian sugar bagasse ashes from the cogeneration industry as active pozzolans for cement manufacture. Cem. Concr. Comp. 2011, 33 (4), 490 - 496.

3. Vegas, I.; Urreta, J.; Frías, M.; García, R. Freeze-thaw resistance of blended cements containing calcined paper sludge. Constr. Build. Mater. 2009, 23 (8), 2862 - 2868.

4.Pereira, M.L.; Jane, S.; Tomazini, F.; Petrisin, C.; Kunihiko, P.; Vieira, A.; Leslie, R. Red mud from Brazil: Thermal behaviour and Physical properties. Ind. Eng. Chem. Res. 2012, 51, 775-786.

5. Loh. Y.R.; Sujan, D.; Rahman, M.E.; Das, C.A. Sugarcane bagasse - The future composite material: A literature Review. Res. Concr. Rec. 2013, 75, 14 - 22.

6. Ekosse, G. (2001). Provenance of the Kgwakgwe kaolin deposit in Southeastern Botswana and its possible utilization. Appl. Clay Sci. 2001, 20, 137-152.

7. Frías, M. Study of Hydrated Phases Present in a MK-Lime System Cured at $60^{\circ} \mathrm{C}$ and 60 Months of Reaction. Cem. Concr. Res. 2006, 36 (5), 827 - 831.

8. Snelson, D.; Wild, S.; O`Farrell, M. Heat of hydration of Portland cement-MK-FA blends. Cem. Concr. Res. 2008, 38(6), 832-840.

9. Siddique, R.; Klaus, J. Influence of metakaolin on the properties of mortar and Concrete: A review. Appl. Clay Sci. 2009, 43(3-4), 392-400.

10. Ríos, C.; Williams, C.; Fullen, M. Hydrothermal synthesis of hydrogarnet and tobermorite at $175^{\circ} \mathrm{C}$ from kaolinite and metakaolinite in the $\mathrm{CaO}-\mathrm{Al}_{2} \mathrm{O}_{3}-\mathrm{SiO}_{2}-\mathrm{H}_{2} \mathrm{O}$ system: A comparative study. Appl. Clay Sci. 2009, $43(2), 228-237$.

11. Frías, M.; Vigil de la Villa, R.; García, R.; Sánchez de Rojas, M.I.; Juan, A. The influence of slate waste activation conditions on mineralogical changes and pozzolanic behavior. J. Am. Cer. Soc. 2013, 96 (7), 2276 $-2282$

12. García-Giménez, R.; Vigil de la Villa Mencía, R.; Rubio, V.; Frías, M. The transformation of coal-mining waste minerals in pozzolanic reactions of cements. Minerals 2016, 6, 64 -70.

13. Finkelman, R.B. Potential health impacts of burning coal beds and waste banks. Int. J. Coal Geol. 2004, 51, 19-24.

14. Suárez-Ruiz, I.; Crelling, J.C. Applied Coal Petrology. The Role of Petrology in Coal Utilization. Elsevier (388 pp), 2008. 
15. Suárez-Ruiz, I.; Flores, D.; Mendonça Filho, J.G.; Hackley, P.C. Review and update of the applications of organic petrology: part 2, geological and multidisciplinary applications. Int. J. Coal Geol. 2012, 98, 73-94.

16. Ribeiro, J.; Suárez-Ruiz, I.; Flores, D. Geochemistry of self-burning coal mining residues from El Bierzo Coalfield (NW Spain): Environmental implications. Int. J. Coal Geol. 2016, 159, 155-168.

17. Nádudvari, A.; Fabiańska, M.J. The impact of water-washing, biodegradation and self-heating processes on coal waste dumps in the Rybnik Industrial Region (Poland). Int. J. Coal Geol. 2016, 154-155, 286-299.

18. Bell, F.G.; Bullock, S.E.T.; Hälbich, T.F.J.; Lindsay, P. Environmental impacts associated with an abandoned mine in the Witbank Coalfield, South Africa. Int. J. Coal Geol. 2001, 45, 195-216.

19. Younger, P.L. Environmental impacts of coal mining and associated wastes: a geochemical perspective. In: Gieré, R., Stille, P. (Eds.), Energy, Waste and the Environment: A Geochemical Perspective. Geological Society, London, Special Publications 236, pp. 169-209, 2004.

20. Bailey, M.T.; Gandy, C.J.; Watson, I.A.; Wyatt, L.M.; Jarvis, A.P. Heat recovery potential of mine water treatment systems in Great Britain. Int. J. Coal Geol. 2016, 164, 77-84.

21. Bian, Z.; Dong, J. The impact of disposal and treatment of coal mining wastes on environment and farmland. Environ. Geol. 2009, 58, 625-634.

22. CEDEX. Monografía sobre Catálogo de Residuos Utilizables en la Construcción, Ficha Técnica, CEDEX, diciembre 2007.

23. Hernández-Mendoza, H.; Mejuto, M.; Cardona, A.I.; García-Álvarez, A.; Millán, R.; Yllera, A. Optimization and validation of a method for heavy metals quantification in soil samples by inductively coupled plasma sector field mass spectrometry (ICP-SFMS). Am. J. Anal. Chem. 2013, 4, 9-15.

24. Chen, X.D. On the fundamentals of diffusive self-heating in water containing combustible materials. Chem. Eng. Process. 1998, 37, 367-378.

25. Garcia, P.; Hall, P.J.; Mondragon, F. The use of differential scanning calorimetry to identify coals susceptible to spontaneous combustion. Thermochim. Acta 1999, 336, 41-46.

26. Lyman, R.; Volkmer, J. Pyrophoricity (spontaneous combustion) of Powder River Basin coals considerations for coalbed methane development. Coal Report CR01-Wyoming State Geological Survey, Laramie, Wyoming, 2001.

27. Kaymakci, E.; Didari, V. Relations between coal properties and spontaneous combustion parameters. Turk. J. Eng. Environ. Sci. 2002, 26, 59-64.

28. Lohrer, C.; Schmidt, M.; Krause, U. Influence of environmental parameters on the self-ignition behavior of coal. Proceedings of the International Conference on Coal Fire Research (29.11.-01.12.2005 Beijing), 2005.

29. Moore, D.M.; Reynolds, R.C. X-ray Diffraction and the Identification and Analysis of Clay Minerals, 2nd edition. Oxford University Press, New York, 1987.

30. Stephan, D.; Maleki, H.; Knofel, D.; Eber, B.; Hardtl, R. Influence of $\mathrm{Cr}, \mathrm{Ni}, \mathrm{Zn}$ on the properties of pure clinker phases. Part I. C3S. Cem. Concr. Res. 1999, 29, 545-552.

31. Vigil de la Villa, R.; Frías, M.; García-Giménez, R.; Martínez Ramírez, S.; Fernández-Carrasco, L. Chemical and mineral transformations that occur in mine waste and washery rejects during pre-utilization calcination. Int. J. Coal Geol. 2014, 132, 123-130. 


\section{Caption of Figures and Tables}

Figure 1- Location map of the study area.

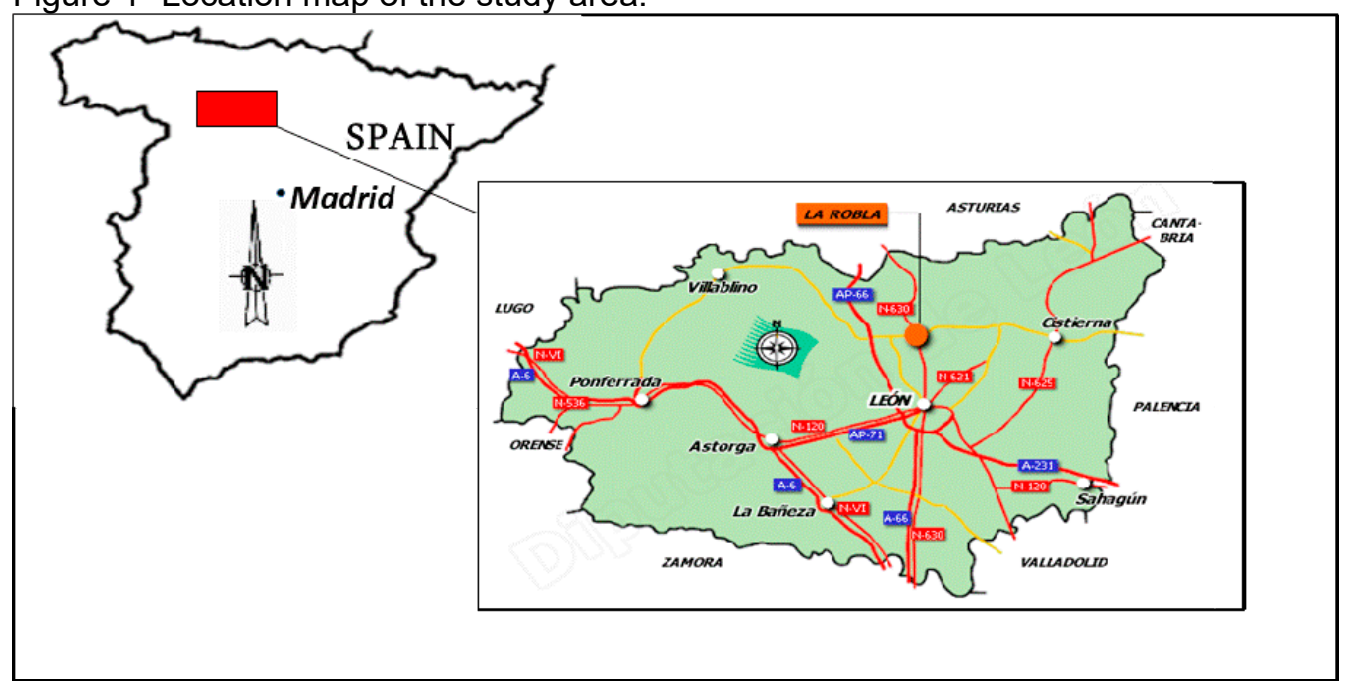

Figure 2- a) General view of the mining exploitation of Santa Lucía (León, Spain). b) Detail of the coal dump material.

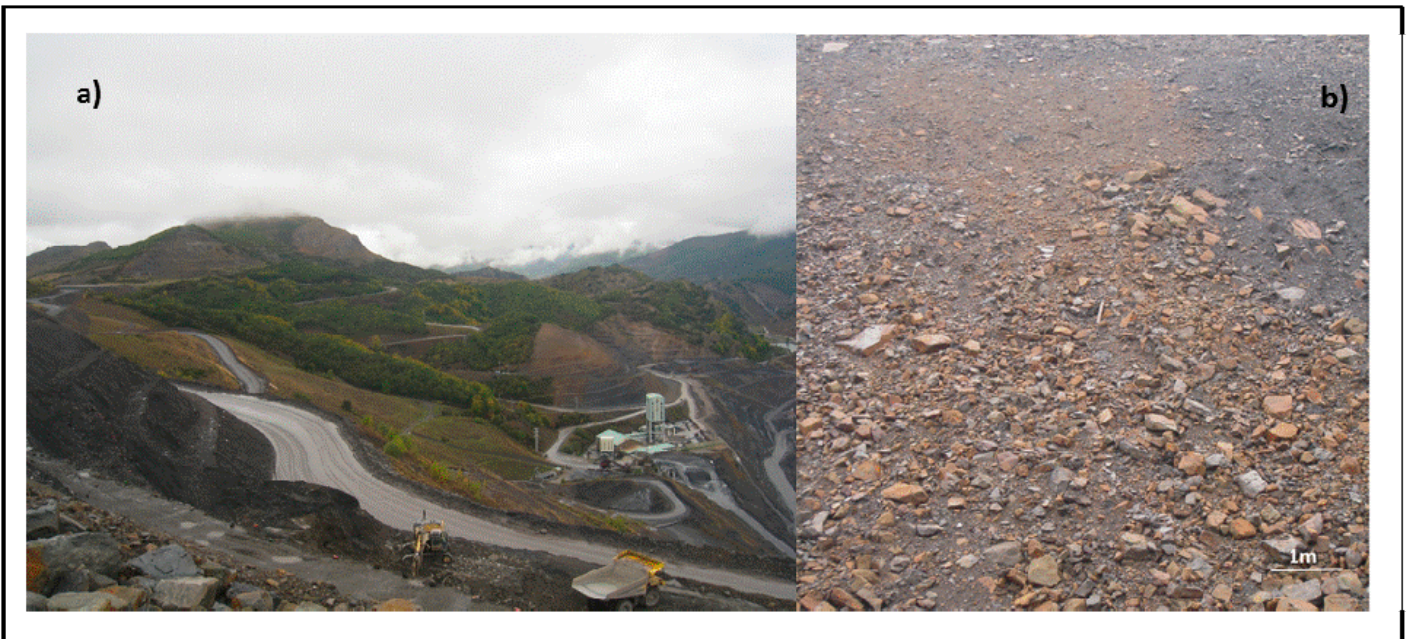

Figure 3- Diffraction spectra of the samples studied. 


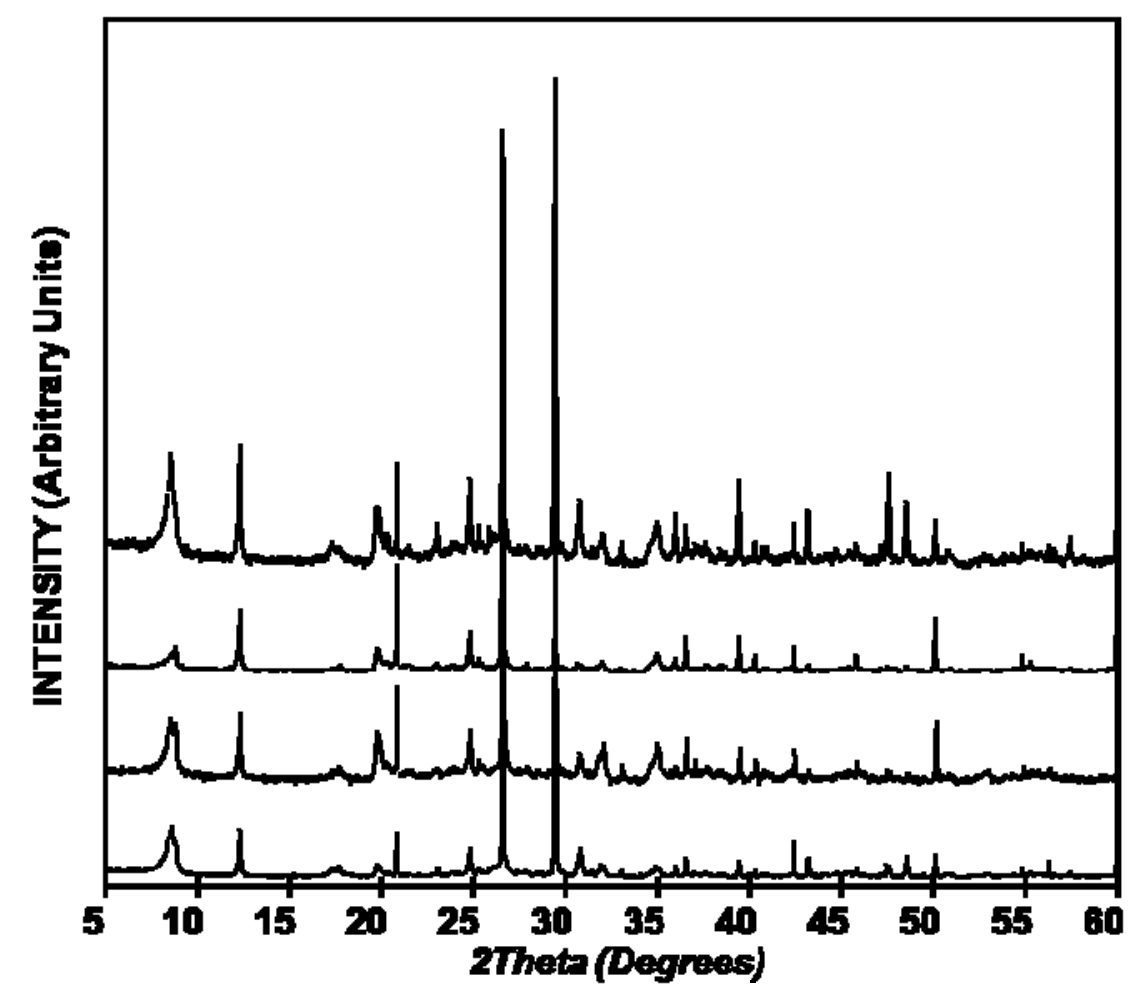

Figure 4- SEM analysis: a) aggregates of variable size in very fine-grade coal sample; b) porous aggregates in very fine-grade coal sample; c) sheets of phyllosilicates in whose cavities there are idiomorphic pyrite crystals in very fine-grade coal sample; d) calcite crystals by rhombohedral exfoliation in very fine-grade coal sample; e) homogeneous size of aggregates in fine tailings coal sample; f) phyllosilicates, quartz and pyrite crystals in fine tailings coal sample. 


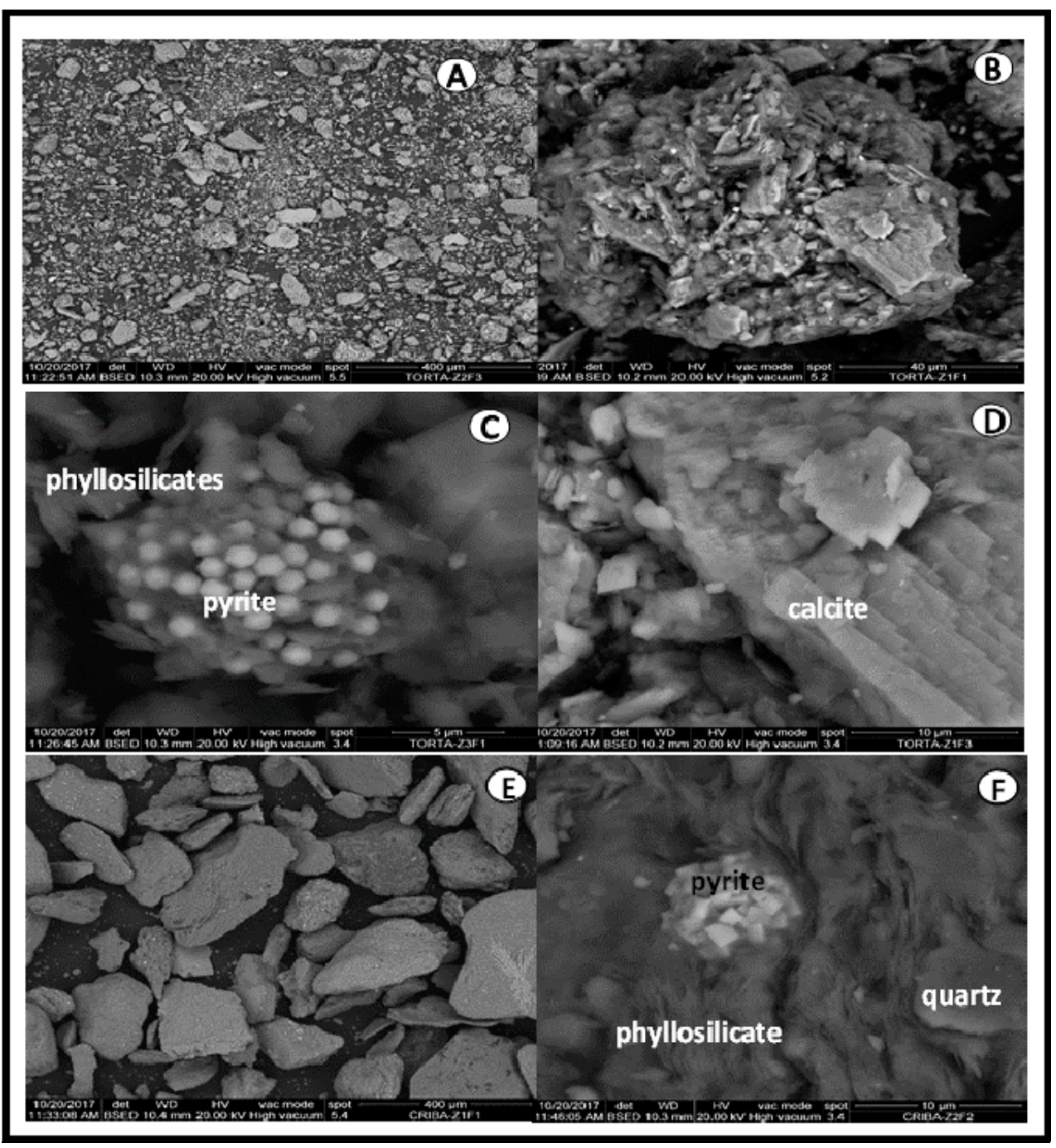

Figure 5.- SEM analysis: a) compact aggregates in coal field sample; b) detail of the coal field sample with clay aggregates that accommodate different ions; c) aggregates of phyllosilicates with folded edges in coal field sample; d) aggregates containing organic matter and pyrite crystals in coal field sample; e) calcite and metakaolinite rhombohedrum in coal field sample activated thermally at $600^{\circ} \mathrm{C}$; f) phyllosilicates detail and metakaolinite in coal field sample activated. 


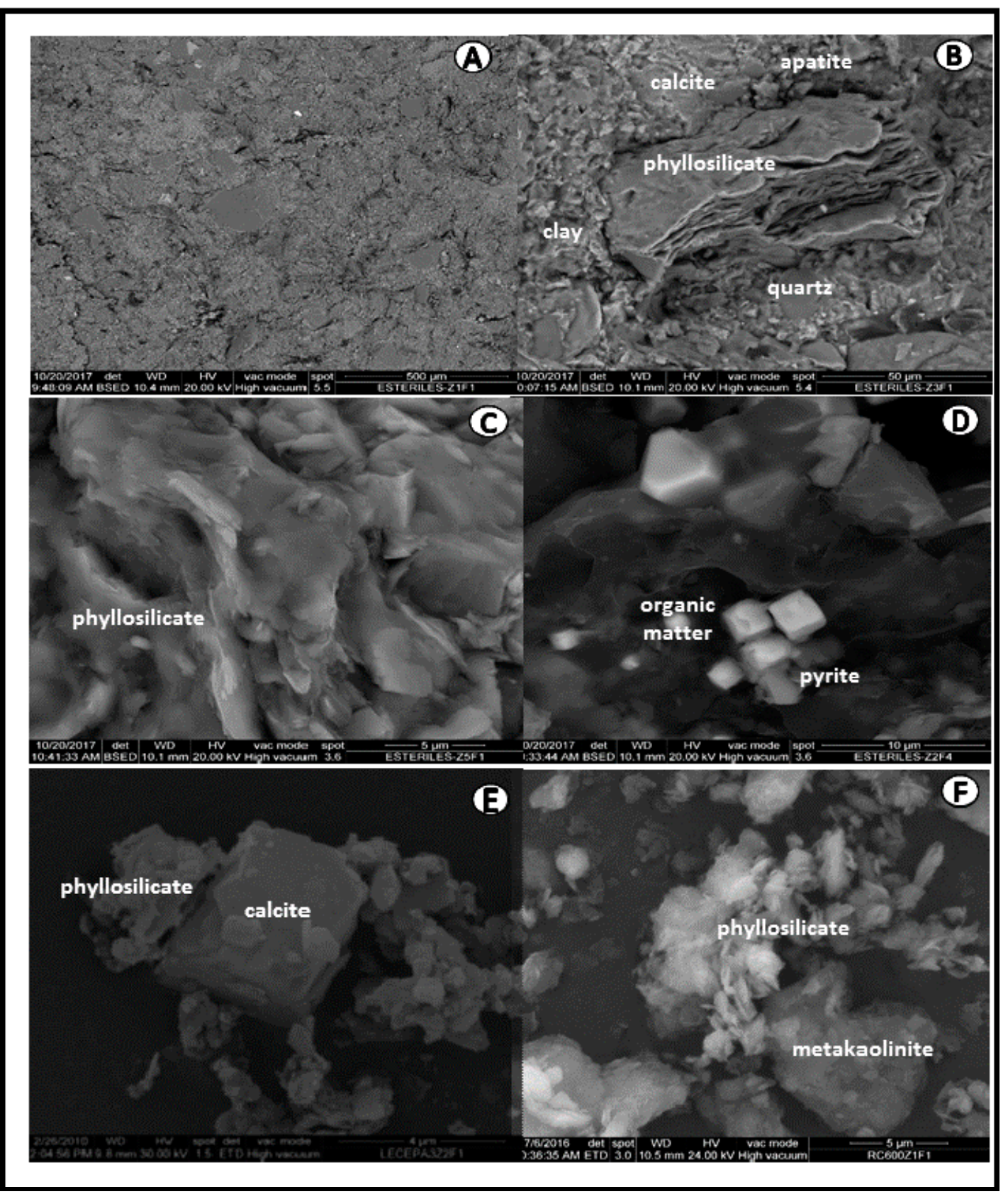

Figure 6- Fixed lime by the coal field (waste dump) sample activated at $600^{\circ} \mathrm{C} / 2$ hours from 1 to 90 days of pozzolanic reaction. 


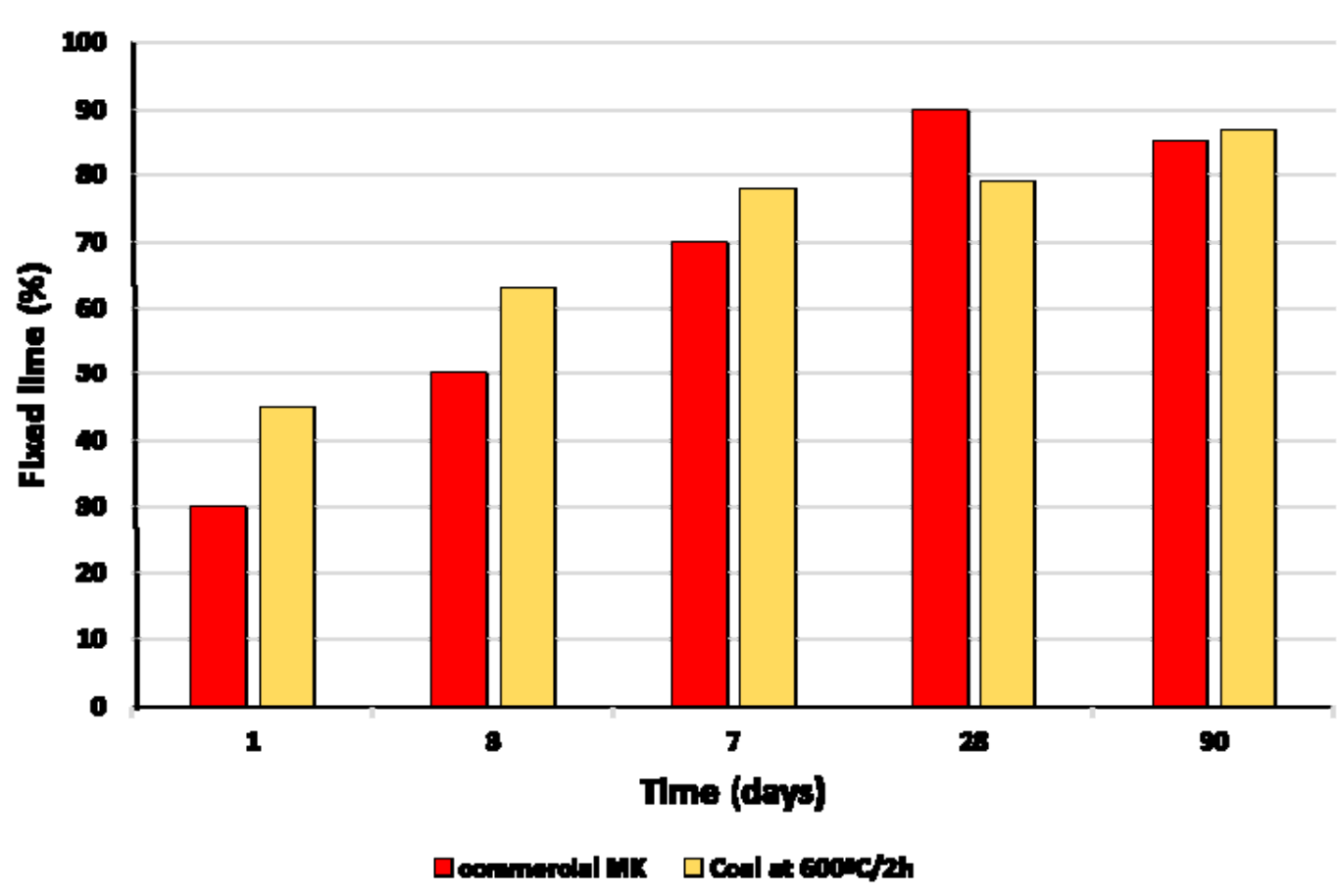

Table 1 - Mineralogical analysis by XRD from the analyzed samples.

\begin{tabular}{ccccc}
\hline \multicolumn{5}{c}{ Tailings } \\
\hline Mineral (\%) & Very fine & Fine & Coarse & $\begin{array}{c}\text { Coal field } \\
\text { (waste } \\
\text { dump }\end{array}$ \\
\hline Mica & 30 & 26 & 28 & 20 \\
Kaolinite & 18 & 6 & 10 & 4 \\
Quartz & 5 & 13 & 10 & 34 \\
Feldspars & traces & traces & traces & traces \\
Calcite & 25 & 30 & 30 & 23 \\
Dolomite & 15 & 10 & 10 & 7 \\
Amorphous & 7 & 15 & 12 & 12 \\
material & & & & 19.6 \\
R & 26.0 & 16.4 & 8.3 & 17.3 \\
Global chi ${ }^{2}$ & 8.6 & 5.4 & & 7.0 \\
\hline
\end{tabular}

Table 2 - Chemical analysis by EDX from the aggregates of very fine grade of coal waste sample.

\begin{tabular}{|c|c|c|c|c|}
\hline Oxides (\%) & Phyllosilicate & Pyrite & Quartz & Calcite \\
\hline $\mathrm{Na}_{2} \mathrm{O}$ & $0.83 \pm 0.22$ & n.d. & n.d. & n.d. \\
\hline $\mathrm{MgO}$ & $0.98 \pm 0.43$ & n.d. & n.d. & n.d. \\
\hline $\mathrm{Al}_{2} \mathrm{O}_{3}$ & $36.31 \pm 1.39$ & n.d. & n.d. & n.d. \\
\hline $\mathrm{SiO}_{2}$ & $54.45 \pm 1.63$ & n.d. & 100 & n.d. \\
\hline $\mathrm{S}^{2-}$ & n.d. & 72.03 & n.d. & n.d.- \\
\hline $\mathrm{Fe}^{2+}$ & n.d. & 27.97 & n.d. & n.d. \\
\hline $\mathrm{K}_{2} \mathrm{O}$ & $4.43 \pm 1.28$ & n.d. & n.d. & n.d. \\
\hline $\mathrm{CaO}^{2}$ & $0.33 \pm 0.12$ & n.d. & n.d. & 100 \\
\hline $\mathrm{TiO}_{2}$ & $1.43 \pm 0.98$ & n.d. & n.d. & n.d. \\
\hline $\mathrm{Fe}_{2} \mathrm{O}_{3}$ & $1.24 \pm 0.85$ & n.d. & n.d. & n.d. \\
\hline
\end{tabular}

n.d. = not detected 
Table 3 - Chemical analysis by EDX of the aggregates from coal field (waste dump) sample.

\begin{tabular}{|c|c|c|c|c|c|c|}
\hline Oxides (\%) & Phyllosilicate & Clay & Apatite & Pyrite & Quartz & Calcite \\
\hline $\mathrm{Na}_{2} \mathrm{O}$ & $0.76 \pm 0.35$ & n.d. & n.d. & n.d. & n.d. & n.d. \\
\hline $\mathrm{MgO}$ & $1.27 \pm 0.63$ & 22.12 & n.d. & n.d. & n.d. & n.d. \\
\hline $\mathrm{Al}_{2} \mathrm{O}_{3}$ & $32.53 \pm 1.58$ & 3.27 & n.d. & n.d. & n.d. & n.d \\
\hline $\mathrm{SiO}_{2}$ & $55.96 \pm 2.41$ & 4.83 & n.d. & n.d. & 100 & n.d. \\
\hline $\mathrm{S}^{2-}$ & n.d. & n.d. & n.d. & 72.03 & n.d. & n.d. \\
\hline $\mathrm{Fe}^{2+}$ & n.d. & n.d. & n.d. & 27.97 & n.d. & n.d. \\
\hline $\mathrm{K}_{2} \mathrm{O}$ & $5.32 \pm 1.93$ & 0.71 & n.d. & n.d. & n.d. & n.d. \\
\hline $\mathrm{CaO}^{2}$ & $1.20 \pm 0.74$ & 44.61 & 53.67 & n.d. & n.d. & 100 \\
\hline $\mathrm{TiO}_{2}$ & $0.54 \pm 0.46$ & n.d. & n.d. & n.d. & n.d. & n.d. \\
\hline $\mathrm{Fe}_{2} \mathrm{O}_{3}$ & $2.39 \pm 1.49$ & 24.46 & n.d. & n.d. & n.d. & n.d. \\
\hline $\mathrm{P}_{2} \mathrm{O}_{5}$ & n.d. & n.d. & 43.33 & n.d. & n.d. & n.d. \\
\hline
\end{tabular}

n.d. = not detected

Table 4- Chemical analysis of the studied samples.

\begin{tabular}{ccccc}
\hline $\begin{array}{c}\text { Oxides } \\
\text { (\%) }\end{array}$ & $\begin{array}{c}\text { Very } \\
\text { fine }\end{array}$ & Fine & Coarse & $\begin{array}{c}\text { Coal field } \\
\text { (waste } \\
\text { dump) }\end{array}$ \\
\hline $\mathrm{SiO}_{2}$ & 32.99 & 41.35 & 43.12 & 49.79 \\
$\mathbf{A l}_{2} \mathbf{O}_{3}$ & 19.90 & 9.37 & 12.16 & 21.77 \\
$\mathrm{Fe}_{2} \mathbf{O}_{3}$ & 4.09 & 4.13 & 4.21 & 4.07 \\
$\mathrm{MnO}_{\mathrm{MgO}}$ & 0.13 & 0.11 & 0.10 & 0.08 \\
$\mathrm{MgO}$ & 0.87 & 0.65 & 0.59 & 0.64 \\
$\mathbf{C a O}$ & 11.44 & 15.21 & 16.20 & 3.84 \\
$\mathrm{Na}_{2} \mathbf{O}$ & 0.35 & 0.32 & 0.25 & 0.13 \\
$\mathbf{S O}_{3}$ & 0.83 & 0.92 & 0.77 & 0.27 \\
$\mathbf{K}_{2} \mathbf{O}$ & 2.11 & 2.18 & 2.27 & 2.74 \\
$\mathrm{TiO}_{2}$ & 0.57 & 0.46 & 0.65 & 1.07 \\
$\mathbf{P}_{\mathbf{2}} \mathbf{O}_{5}$ & 0.26 & 0.16 & 0.22 & 0.13 \\
$\begin{array}{c}\text { Loss on } \\
\text { ignition }\end{array}$ & 26.47 & 25.14 & 19.46 & 15.18 \\
Organic & 24.27 & 21.54 & 18.14 & 16.04 \\
carbon & & & & \\
\hline
\end{tabular}

Table 5 - Chemical analysis of the minor elements in the studied samples (n.d. = not detected).

\begin{tabular}{ccccc}
\hline $\begin{array}{c}\text { Element } \\
\text { (mg/L) }\end{array}$ & $\begin{array}{c}\text { Very } \\
\text { fine }\end{array}$ & Fine & Coarse & $\begin{array}{c}\text { Coal field } \\
\text { (waste } \\
\text { dump }\end{array}$ \\
\hline $\mathbf{C u}$ & n.d. & n.d. & n.d. & n.d. \\
$\mathbf{N i}$ & 50 & 63 & 77 & 26 \\
$\mathbf{C r}$ & 100 & 150 & 176 & 98 \\
$\mathbf{V}$ & 88 & 103 & 133 & 112 \\
$\mathbf{Z n}$ & 10 & 18 & 30 & 32 \\
$\mathbf{P b}$ & 3 & 4 & 3 & 5 \\
$\mathbf{C d}$ & $\mathrm{n} . \mathrm{d}$. & $\mathrm{n} . \mathrm{d}$. & $\mathrm{n} . \mathrm{d}$. & $\mathrm{n} . \mathrm{d}$. \\
$\mathbf{A s}$ & 2 & 2 & 2 & 2 \\
$\mathbf{C o}$ & 11 & 15 & 12 & 8 \\
Mo & 18 & 15 & 17 & 21 \\
\hline
\end{tabular}


Table 6 - Mineralogical composition by XRD from the coal field (waste dump) sample activated termically between $500^{\circ}$ and $900^{\circ} \mathrm{C}$ (n.d. = not detected).

\begin{tabular}{llllll}
\hline Mineral (\%) & $\mathbf{5 0 0 ^ { \circ } \mathbf { C }}$ & $\mathbf{6 0 0}^{\circ} \mathbf{C}$ & $\mathbf{7 0 0}^{\circ} \mathbf{C}$ & $\mathbf{8 0 0}^{\circ} \mathbf{C}$ & $\mathbf{9 0 0}^{\circ} \mathbf{C}$ \\
\hline Mica & 20 & 20 & 17 & 17 & 7 \\
Kaolinite & 4 & n.d. & n.d. & n.d. & n.d. \\
Quartz & 34 & 42 & 51 & 46 & 41 \\
Spinel & n.d. & 1 & 5 & 6 & 6 \\
Hematite & n.d. & 3 & 4 & 6 & 10 \\
Calcite & 25 & 22 & 3 & n.d. & n.d. \\
Dolomite & 7 & n.d. & n.d. & n.d. & n.d \\
Amorphous & 10 & 12 & 20 & 25 & 30 \\
material & & & & & \\
R & 26.8 & 20.9 & 19.4 & 18.5 & 18.9 \\
Global $\mathbf{c h i}^{2}$ & 14.7 & 9.7 & 6.8 & 6.0 & 12.3 \\
\hline
\end{tabular}

Table 7. Chemical analysis by EDX of the aggregates from coal field (waste dump) sample activated at $600^{\circ} \mathrm{C}$.

\begin{tabular}{|c|c|c|}
\hline Oxides (\%) & Phyllosilicate & Metakaolinite \\
\hline $\mathrm{MgO}$ & 0.97 & n.d. \\
\hline $\mathrm{Al}_{2} \mathrm{O}_{3}$ & 26.55 & 35.62 \\
\hline $\mathrm{SiO}_{2}$ & 61.69 & 58.58 \\
\hline $\mathrm{SO}_{3}$ & 3.22 & 1.00 \\
\hline $\mathrm{K}_{2} \mathrm{O}$ & 3.10 & 2.92 \\
\hline $\mathrm{CaO}$ & 1.41 & 1.89 \\
\hline $\mathrm{TiO}_{2}$ & 0.88 & n.d. \\
\hline $\mathrm{Fe}_{2} \mathrm{O}_{3}$ & 2.17 & n.d. \\
\hline
\end{tabular}

n.d. $=$ not detected 